\title{
Sialendoscope-assisted transoral removal of hilo-parenchymal sub-mandibular stones: surgical results and subjective scores
}

\section{L'asportazione transorale scialoendoscopico-assistita dei calcoli ilo-parenchimali sottomandibolari: risultati chirurgici e soggettivi}

\author{
P. CAPACCIO ${ }^{12}$, M. GAFFURI ${ }^{1}$, V. ROSSI ${ }^{12}$, L. PIGNATARO ${ }^{13}$ \\ ${ }^{1}$ Department of Otolaryngology and Head and Neck Surgery, Fondazione IRCCS Ca' Granda Ospedale Maggiore \\ Policlinico, Milan, Italy; ${ }^{2}$ Department of Biomedical, Surgical, Dental Sciences; ${ }^{3}$ Department of Clinical Sciences \\ and Community Health, University of Milan, Italy
}

\begin{abstract}
SUMMARY
It has been suggested that a conservative trans-oral approach to proximal and hilo-parenchymal submandibular stones (HPSMS) is a valid alternative to the more frequently used sialadenectomy. The aim of this study was to evaluate the surgical, ultrasonographic and patients' subjective outcomes of results of the trans-oral removal of HPSMS. Between January 2003 and September 2015, sialendoscope-assisted trans-oral surgery was used to remove symptomatic, large $(>7 \mathrm{~mm})$, fixed and palpable HPSMS from 479 patients under general anaesthesia. All patients were followed clinically and ultrasonographically to investigate symptom relief and recurrence of stones, and were telephonically interviewed to assess saliva-related subjective outcomes with a questionnaire. Stones were successfully removed from 472 patients $(98.5 \%)$; the seven failures $(1.5 \%)$ concerned pure parenchymal stones. One year after the procedure, 408 patients $(85.1 \%)$ were symptom free, $59(12.3 \%)$ had recurrent obstructive symptoms and $12(2.6 \%)$ had recurrent infections. Of the 54 patients who developed a recurrent stone (11.2\%), 52 underwent a second procedure: 29 interventional sialendoscopies, two sialendoscope-assisted intra-corporeal pneumatic lithotripsy, eight secondary transoral surgery to remove residual stones, six a cycle of extra-corporeal lithotripsy and seven submandibular sialadenectomy. Most patients (75.2\%) reported mild surgery-related pain. The symptoms of 454 patients (94.8\%) improved after adjunctive treatment and, at the end of follow-up, the affected gland was preserved in $98.5 \%$ of patients. A sialendoscope-assisted trans-oral removal of large HPSMS is a safe, effective, conservative surgical procedure, and functional preservation of the main duct and parenchyma of the obstructed gland allows sialendoscopic access through the natural ostium in case of recurrence. Combining a trans-oral approach with other minimally invasive, conservative procedures ensures symptomatic relief and salivary duct system clearance in the majority of patients.
\end{abstract}

KEY WORDS: Submandibular stones $\bullet$ Transoral surgery $\bullet$ Sialendoscopy $\bullet$ Submandibular sialadenectomy $\bullet$ Hyloparenchymal stones

\section{RIASSUNTO}

Come si evince dall'analisi della letteratura, l'approccio transorale ai calcoli prossimali e ilo-parenchimali della ghiandola sottomandibolare rappresenta una valida alternativa alla scialoadenectomia tradizionale. Lo scopo di questo studio è quello di valutare $i$ risultati chirurgici, ecografici e soggettivi di questa tecnica conservativa. Tra Gennaio 2003 e Settembre 2015 sono stati trattati con l'approccio transorale scialoendoscopico-assistito 479 pazienti affetti da calcoli ilo-parenchimali sottomandibolari palpabili, non mobili, di dimensioni superiori ai $7 \mathrm{~mm}$. Tutti i pazienti sono stati sottoposti ad un follow-up clinico, ecografico e ad una valutazione soggettiva dell'outcome chirurgico per mezzo di un apposito questionario somministrato attraverso un'intervista telefonica. Il successo chirurgico definito come completa asportazione del calcolo ilo-parenchimale è stato ottenuto in 472 pazienti (98.5\%); in sette casi (1.5\%) si è verificato un insuccesso chirurgico, riguardante esclusivamente calcoli parenchimali puri. Un anno dopo l'intervento chirurgico, 408 pazienti (85.1\%) non riferivano più sintomi ostruttivi, 59 pazienti (12.3\%) riferivano sintomi ostruttivi ricorrenti e $12(2.6 \%)$ infezioni ricorrenti. Dei 54 pazienti (11.2\%) affetti da litiasi sottomandibolare ricorrente, 52 sono stati sottoposti ad una seconda procedura terapeutica, nello specifico in 29 casi a scialoendoscopia, in 2 casi a litotrissia pneumatica intracorporea, in 8 casi a chirurgia transorale, in 6 casi ad un ciclo di litotrissia extracorporea, in 7 casi a scialoadenectomia sottomandibolare. La maggior parte dei pazienti (75.2\%) ha riferito un dolore post-chirurgico di grado lieve. Al termine del follow-up, i sintomi riferiti da 454 pazienti (94.8\%) erano migliorati dopo il secondo trattamento e la ghiandola sottomandibolare affetta era stata preservata nel 98.5\% dei casi. La chirurgia transorale scialoendoscopico-assistita dei calcoli ilo-parenchimali della ghiandola sottomandibolare rappresenta un'opzione terapeutica sicura, efficace e conservativa e la preservazione del dotto e del parenchima ghiandolare permette di esplorare il sistema duttale attraverso l'ostio naturale in caso di ricorrenza della patologia. L'utilizzo combinato dell'approccio transorale e delle altre tecniche mini-invasive permette di trattare con successo la maggior parte dei pazienti affetti da litiasi ilo-parenchimale sottomandibolare.

PAROLE CHIAVE: Calcoli sottomandibolari $\bullet$ Chirurgia transorale $\bullet$ Scialoendoscopia $\bullet$ Scialoadenectomia sottomandibolare $\bullet$ Calcoli ilo-parenchimali 


\section{Introduction}

Sialolithiasis accounts for about $50 \%$ of benign obstructive salivary gland diseases ${ }^{1}$, the annual symptomatic incidence of which has recently been estimated to be $1 / 10$ 30,000 subjects $^{2}$.

The submandibular glands (SMGs) are the most frequently affected $(80-90 \%)^{3}$ because of the narrow opening of Wharton's duct, its ascendant course and length, and the mainly mucous composition of saliva ${ }^{4}$, and the most frequent locations of SMG stones are the distal tract of the duct and hilum (pure intraparenchymal stones account for $<10 \%)^{5}$. Typical symptoms are recurrent swelling and pain at mealtimes. In many cases, careful palpation of the oral floor allows the exact position of a stone to be detected, and diagnosis can be confirmed radiologically by ultrasonography (US) ${ }^{6}$, conventional radiography, computed tomography (CT) and/or cone beam tomography $(\mathrm{CBCT})^{7}$.

Despite its known risks ${ }^{8}$, sialadenectomy is still the most widely used procedure to treat proximal and HPSMS ${ }^{9}$, but a conservative approach has emerged as a valid alternative ${ }^{1011}$. It has been shown that trans-oral removal of large $(>7 \mathrm{~mm})$ and deeply located submandibular stones $^{10}{ }^{11}$, the spread of which has been favoured by the development of interventional sialendoscopy, is safe and effective ${ }^{11}$, and highly successful in terms of stone removal and symptom relief ${ }^{611}$. A sialendoscope-assisted procedure is useful because the brightness can help in detecting any residual intraparenchymal stones after removal of the main HPSMS ${ }^{12}$, thus ensuring the complete clearance of the ductal system and eliminating symptoms of mealtime syndrome. On the basis of our previous findings ${ }^{11}$, it can be expected that only a small percentage of patients experience (often asymptomatic) stone recurrence, especially those previously treated by extra-corporeal shock wave lithotripsy (ESWL) in whom the parenchymal spread of micro-debris may not be detected by US or during surgical exploration through the oral hilo-parenchymal opening of the submandibular gland ${ }^{1314}$.

As a surgical procedure needs to be assessed on the basis of objective surgical and subjective patient perceived results measured using validated questionnaires ${ }^{15}$, the aim of this study was to assess the surgical, US and subjective outcomes in a large series of patients who underwent trans-oral removal of a large HPSMS and who were followed in the long term.

\section{Materials and methods}

Between January 2003 and September 2015, 479 patients (235 females) with a mean age of 46 years (range 19-81) underwent sialendoscope-assisted trans-oral surgical removal of symptomatic, large ( $>7 \mathrm{~mm}$ ), fixed and palpable HPSMS at the Department of Otolaryngology and Head and Neck Surgery of Fondazione IRCCS Ca' Granda Policlinico in Milan, 14 of whom had been previously and unsuccessfully treated by ESWL. All patients underwent US and Doppler US assessments (Hitachi H21, 7.5 MHz, Hitachi High Technology Corporation Ltd., Tokyo, Japan) and clinical evaluation to establish the size of the stone (minimum diameter $7 \mathrm{~mm}$ ) and its location, which was clinically defined as hilar when at least two margins were detectable during bimanual palpation of the oral floor, hilo-parenchymal when only the distal margin was detectable during palpation and the remaining margins were covered by glandular tissue, and intra-parenchymal when completely covered by glandular tissue ${ }^{20}$. Exclusion criteria were an inability to open the mouth sufficiently and presence of non-palpable stones.

\section{Surgical procedure}

The procedure was performed under general anaesthesia with headlight illumination and loupe magnification. With the mouth held open by a small gag, the tongue was retracted antero-medially, and the floor of the mouth was infiltrated by $5 \mathrm{~mL}$ of mepivacaine $25 \mathrm{mg} / \mathrm{mL}+$ adrenaline $5 \mu \mathrm{g} / \mathrm{mL}$ just below the oral mucosa. The duct was identified and cannulated using a salivary probe (Bowman probes, Karl Storz, Tuttlingen, Germany). An oblique incision was made near the papillary region of Wharton's duct, along the floor of the mouth toward the second molar. Once the mucosa was parted, the loose areolar tissue was dissected (first by means of sharp-tipped, and then with smooth-tipped scissors) medially to the internal edge of the sublingual gland, which was rotated laterally to expose Wharton's duct. The horseshoe-shaped lingual nerve is easily identified running obliquely from the tongue, passing under the duct, and then ascending medially through the tail of the sublingual gland over Wharton's duct to run below the constrictor muscles to the infra-temporal fossa. The lingual nerve was mobilised from the duct and retracted medially to visualise the stone in the gland hilum, which was moved upward to the submandibular gland area by external finger pressure. An incision was made over the calculus, and the stone was delivered using a micro- or Freer elevator (Martin, Tuttlingen, Germany); submandibulotomy was performed in the case of intraparenchymal stones (Fig. 1). The cavity was then irrigated with saline to clear any debris and a haemostatic and anti-microbial fibrillar surgical net (Tabotamp, Johnson \& Johnson Medical Limited, Gargrave, Skipton, UK) was positioned over the hilar opening to avoid the risk of stricture or stenosis. Finally, the wound was irrigated with antibiotic solution (rifampicin), and the oral floor was sutured using resorbable stitches (3.0 Vicryl). In the case of ostial stenosis, the distal third of the duct can be rehabilitated by making an axial incision and inserting a 6F polymeric salivary stent (Optimed, Ettlingen, Germany) or a 14-20 G Venflon tube (Artsana, Grandate, Italy) 


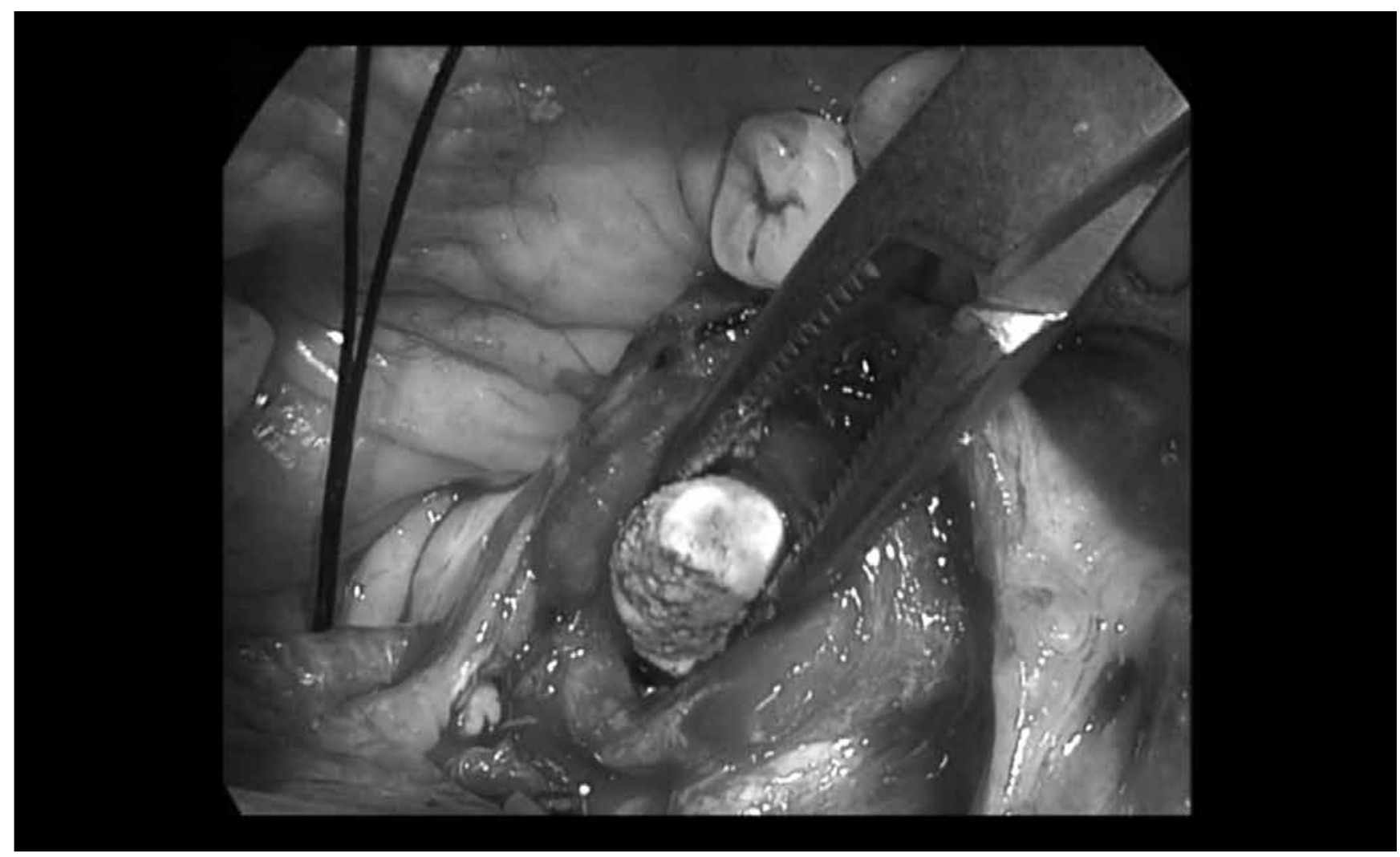

Fig. 1. Release of a hilo-parenchymal submandibular stone during sialendoscope-assisted transoral surgery.

attached to the oral floor with a resorbable suture, which are usually removed after two weeks.

Sialendoscopy (0.8-1.1 mm, Erlangen sialoendoscopes, Karl Storz Co., GmbH, Tuttlingen, Germany) is used to better locate the stone in the hilo-parenchymal, or to check for any residual intra-parenchymal stones or debris through the incision.

All patients received antibiotic therapy (amoxicillin and clavulanic acid) for one week after the procedure; steroids were also administered in the case of oral floor oedema.

\section{Post-operative follow-up}

Patients were clinically re-examined after one week, one month and one year to evaluate the course of wound healing and recovery of clear secretory flow from the papilla after gland massage, and any early or late post-operative complications were assessed. They were also offered US examination one year after the procedure to check the echogenicity of the glandular parenchyma and ascertain any ductal system dilation or residual stones.

All patients were telephoned to ask for saliva-related subjective outcomes using a questionnaire created to measure trans-oral surgical outcomes on the basis of the proposal of Gillespie et al. ${ }^{15}$ They were asked to describe any improvement in symptoms and to grade surgery-related pain with a $0-10$ visual analogue scale (VAS, in which $0=$ no pain, and $10=$ maximum pain). In the case of residual symptoms, the patients were asked about any further treatments (antibiotics or surgery) and grade the average pain felt using the same scale. Finally, they were asked if they would repeat and recommend trans-oral surgery to other patients.

\section{Results}

The US-measured size of stones ranged from seven to 26 $\mathrm{mm}$ (mean 10, median $9 \mathrm{~mm}$ ). The stones were located in the right SMG in 223 patients (46.5\%), the left SMG in 244 patients $(51 \%)$, and bilaterally in 12 patients $(2.5 \%)$; 233 patients $(48.7 \%)$ had hilar stones, 188 (39.3\%) hiloparenchymal stones and $58(12 \%)$ intra-parenchymal stones. The stones were successfully removed from 472 patients $(98.5 \%)$; the seven failures $(1.5 \%)$ concerned pure parenchymal stones that could not be detached from the gland tissue despite the parenchymal incision (Table I). Only 44 patients $(9.2 \%)$ underwent a sialendoscopeassisted procedure to locate an intra-parenchymal stone more precisely through the papillary ostium, $(n=18)$ or check for any residual parenchymal stones through the hilar opening $(n=26)$. No intra-operative complications were encountered.

Early sequelae were observed in 365 patients $(76.1 \%)$ (Table II). These consisted of transient gland swelling ( $\mathrm{n}=125)$, variable swelling and oedema of the mouth floor $(n=122)$, tingling of the tip of the tongue $(n=108)$ 
Table I. Demographic and clinical characteristics of patients undergoing the sialendoscope-assisted trans-oral surgical removal of hilo-parenchymal stones.

\begin{tabular}{lcc} 
& $\mathbf{n}$ & $\%$ \\
Gender & & \\
Male & 244 & 50.9 \\
Female & 235 & 49.1 \\
Previous treatments & & \\
None & 465 & 97.1 \\
Shock wave lithotripsy & 14 & 2.9 \\
Side & & \\
Right & 223 & 46.5 \\
Left & 244 & 51 \\
Bilateral & 12 & 2.5 \\
Site & & \\
Hilar & 233 & 48.7 \\
Hilo-parenchymal & 188 & 39.3 \\
Intraparenchymal & 58 & 12 \\
Intra-operative complications & & \\
Yes & 0 & 0 \\
No & 479 & 100 \\
Surgical results & & \\
Success & 472 & 98.5 \\
Failure & 7 & 1.5 \\
\hline
\end{tabular}

Table II. Follow-up of patients undergoing conservative transoral surgery.

\begin{tabular}{lcc} 
Early sequelae & $\mathbf{n}$ & $\%$ \\
\hline None & 114 & 23.9 \\
Swelling only & 125 & 26.1 \\
Swelling and oedema & 122 & 25.4 \\
Tingling & 108 & 22.5 \\
Lingual nerve injury (transient) & 10 & 2.1 \\
\hline Late complications & & \\
\hline None & 452 & 94.4 \\
Oral mycosis & 0 & 0 \\
Tingling & 3 & 0.6 \\
Ranula & 0 & 0 \\
Hilar stenosis & 24 & 5 \\
Lingual nerve injury (persistent) & 0 & 0 \\
\hline Follow-up results & & \\
No residual stones at US & 425 & 88.7 \\
Residual stones at US & 54 & 11.3 \\
\hline Subjective evaluation & & \\
\hline No symptoms & 408 & 85.1 \\
Recurrent obstructive symptoms & 59 & 12.3 \\
Recurrent infections & 12 & 2.6 \\
\hline Post-surgery treatments & & \\
\hline Interventional sialendoscopy & 31 & 43.7 \\
Other transoral removal & 8 & 11.3 \\
Sialoadenectomy & 7 & 9.8 \\
ESWL & 6 & 8.6 \\
None & 19 & 26.6 \\
\hline
\end{tabular}

and transient lingual nerve injury $(\mathrm{n}=10)$. Only 27 patients $(5.6 \%)$ experienced late complications: persistent tingling of the tip of the tongue $(n=3)$ and recurrent sialadenitis due to partial hilar stenoses revealed by US $(n=24)$. None of the patients experienced permanent lingual nerve injury.

All patients were clinically followed at one and 12 months after the surgical procedure: $408(85.1 \%)$ were symptom free, $59(12.3 \%)$ had recurrent obstructive symptoms and $12(2.6 \%)$ had recurrent infections. US examination at one year showed that parenchymal echogenicity and vascularisation had normalised in most patients, but 54 (11.2\%) had developed a subsequent stone (diameter 2-6 $\mathrm{mm})$. The size of the gland was normal in 32 patients, increased in 13 and decreased in 9 patients; no ductal dilation was observed in 40 patients, whereas six showed mild hilar dilation and eight dilation within the ductal system. Of the 71 patients with recurrent obstructive symptoms or infections, 29 underwent secondary interventional sialendoscopy, two sialendoscopy-assisted pneumatic intracorporeal lithotripsy; eight a secondary trans-oral procedure to remove residual stones, six a cycle of extra-corporeal lithotripsy, and seven submandibular sialadenectomy. The remaining 19 did not undergo any further procedure.

Trans-oral surgery led to resolution of symptoms (defined as the absence of any residual episodes of painful salivary gland swelling) in 408 patients $(85.1 \%)$ (Table III). Most patients $(75.2 \%)$ reported mild surgery-related pain (VAS scores $1-5$ ), but $24.8 \%$ experienced moderate pain (VAS scores 6-10); during the course of follow-up, 71 patients $(14.9 \%)$ experienced recurrent swelling and moderate pain, with $29(40.5 \%)$ recording a mean VAS score of 8: further treatments consisted of medical therapy alone in 25 patients $(35.2 \%)$, and repeat surgery in 46 (64.8\%). Symptoms improved after adjunctive treatment in 454 patients $(94.8 \%)$ and, at the end of follow-up, the affected gland was intact in $98.5 \%$ of cases. The vast majority of patients $(99.6 \%)$ said they would repeat and recommend sialendoscope-assisted trans-oral treatment.

\section{Discussion}

A trans-oral approach has recently been proposed as a gland-preserving alternative to sialadenectomy for deep and parenchymal stones ${ }^{46}$. The main limitations of previously published studies are that many also included stones located in the main submandibular duct, very few describe long-term surgical results and none considered patients' subjective perceptions or QoL factors. A further curiosity is that a combined sialendoscopy and trans-oral procedure has been advocated, although it is difficult to understand how sialendoscopy can influence the result of trans-oral stone removal.

We describe the objective and subjective outcomes of conservative sialendoscopy-assisted transoral surgery for 
Table III. Patient's subjective findings after surgery for hilo-parenchymal submandibular stones.

\begin{tabular}{lcc} 
& $\mathbf{n}$ & $\%$ \\
\hline Symptoms resolved after first treatment & 408 & 85.1
\end{tabular}

\begin{tabular}{|c|c|c|}
\hline \multicolumn{3}{|l|}{ Pain secondary to trans-oral surgery $(1-10)$} \\
\hline 1 & 3 & 0.6 \\
\hline 2 & 56 & 11.8 \\
\hline 3 & 75 & 15.7 \\
\hline 4 & 114 & 23.7 \\
\hline 5 & 112 & 23.4 \\
\hline 6 & 63 & 13.2 \\
\hline 7 & 44 & 9.1 \\
\hline 8 & 12 & 2.5 \\
\hline 9 & 0 & 0 \\
\hline 10 & 0 & 0 \\
\hline $\begin{array}{l}\text { Residual symptoms - recurrent swelling and } \\
\text { pain }(5-10)\end{array}$ & 71 & 14.9 \\
\hline 5 & 5 & 7.6 \\
\hline 6 & 17 & 24.1 \\
\hline 7 & 18 & 25.3 \\
\hline 8 & 29 & 40.5 \\
\hline 9 & 2 & 2.5 \\
\hline 10 & 0 & 0 \\
\hline Further treatment required & 71 & 14.9 \\
\hline Antibiotics & 25 & 35.2 \\
\hline Surgery & 46 & 64.8 \\
\hline \multicolumn{3}{|l|}{ Improved symptoms after multiple treatments } \\
\hline Yes & 454 & 94.8 \\
\hline No & 25 & 5.2 \\
\hline \multicolumn{3}{|l|}{ Intact gland } \\
\hline Yes & 472 & 98.5 \\
\hline No & 7 & 1.5 \\
\hline \multicolumn{3}{|l|}{ Would repeat treatment } \\
\hline Yes & 477 & 99.6 \\
\hline No & 2 & 0.4 \\
\hline \multicolumn{3}{|l|}{ Would recommend treatment } \\
\hline Yes & 477 & 99.6 \\
\hline No & 2 & 0.4 \\
\hline
\end{tabular}

large, palpable submandibular stones in a large series of 479 patients. The stones, which were all clinically and ultrasonographically classified as intra-parenchymal, were successfully retrieved from all but seven patients, in whom the failure was due to the fact that the stone could not be separated from the gland tissue despite the use of dedicated elevators. This good result is in line with our initial experience ${ }^{1}$ and what has been reported by other authors ${ }^{4616}$, and demonstrate that the procedure is effective in removing deep submandibular stones. Most of these can be removed without using a sialendoscope but, in $9 \%$ of cases, the bright guidance of the sialendoscopic unit facilitated the search for residual parenchymal microliths that had cracked during removal of the main stone or migrated backwards to the peri-hilar region.

On the basis of our data, the technique can be considered safe as only a small number of patients experienced what were only mild untoward effects, such as tingling of the tip of the tongue or the persistence of recurrent sialadenitis due to a US-revealed hilar stenosis.

During follow-up, $85.1 \%$ of patients were considered asymptomatic although US allowed the discovery of a number of residual stones in $11.2 \%$ of them, 52 of whom were able to undergo a secondary procedure that was made possible by preservation of the entire ductal system. Thirty-one underwent interventional sialendoscopy (including two who underwent sialendoscope-assisted pneumatic intracorporeal lithotripsy); eight underwent a second trans-oral procedure to remove residual stones; and six underwent a cycle of extra-corporeal lithotripsy. Traditional sialadenectomy was required in only seven patients with undetachable parenchymal stones; as failure is a possible event in the case of deep intra-glandular stones, informed double consent to concomitant sialadenectomy should be considered before surgery.

We have previously found ${ }^{12}$ that recurrences mainly occur in the first 12 post-procedural months due to the persistence of micro-debris in the gland parenchyma that cannot be detected by US, something that is more frequently observed in patients who have previously undergone shock wave lithotripsy ${ }^{1718}$. Consequently, extra-corporeal lithotripsy should be used in combination with trans-oral surgery only as salvage therapy after surgery and not before. A new intra-corporeal lithotripter was successfully used in our patients with residual fragments after surgery. This new technique, which has recently been described by Koch et al. ${ }^{19}$, seems to work well and may well become an alternative to trans-oral surgery in selected patients in the future. Multiple microliths are frequently encountered near the main stone during diagnostic work-up, but cannot be visualised by US even by an experienced radiologist. The risk of undiagnosed stones that may otherwise be left in the salivary duct system during surgery (especially in the case of a secondary approach) could possibly be reduced by combining US and cone beam 3D CT, as is currently done in the case of many ENT disorders ${ }^{20}$.

Post-operative US showed that the ductal and parenchymal characteristics of most patients normalised which, together with the significant reduction in the number of episodes of sialadenitis and the subjective perceptions reported by patients, confirms that obstructive sialadenitis is reversible ${ }^{17}$.

\section{Conclusions}

Sialendoscope-assisted trans-oral removal of large (> $7 \mathrm{~mm}$ ) hilo-parenchymal submandibular stones is a 
safe and effective conservative surgical procedure. It preserves the main submandibular duct and allows the stone to be removed through a minimal incision in the hilo-parenchymal region, thus ensuring functional preservation of the obstructed gland and allowing sialendoscopic access through the natural ostium in the case of recurrence. At the same time, a multimodal approach combining all minimally invasive and conservative procedures (such as extra- and intra-corporeal lithotripsy and interventional sialendoscopy) can be planned to provide symptomatic relief and clearance of the salivary duct system. Pre-operative clinical and US evaluation is always advisable to locate the stone precisely and minimise the risk of failure, especially in the case of pure intra-parenchymal stones. Particular attention should be paid to initial experiences with the newly available system of sialendoscope-assisted pneumatic lithotripsy as this will probably reduce the number of patients undergoing trans-oral surgery for large stones. Although it cannot be defined as minimally invasive, most patients would be prepared to repeat the procedure and recommend it to others as it avoids the risks of traditional invasive external surgery.

\section{References}

1 Capaccio P, Torretta S, Ottaviani F, et al. Modern management of obstructive salivary diseases. Acta Otorhinolaryngol Ital 2007;27:161-72.

2 Sigismund PE, Zenk J, Koch M, et al. Nearly 3,000 salivary stones: some clinical and epidemiologic aspects. Laryngoscope 2015;125:1879-82.

3 Gillespie MB, Koch M, Iro H, et al. Endoscopic-assisted gland-preserving therapy for chronic sialadenitis: a German and US comparison. Arch Otolaryngol Head Neck Surg 2011;137:903-8.

4 Rauch S, Gorlin RJ. Diseases of the salivary glands. In: Gorlin RJ, Goldman HM, editors. Thoma's Oral Pathology. Sixth edition. St Louis: Mosby; 1970. p. 997-1003.

5 Zenk J, Constantinidis J, Al-Kadah B, et al. Transoral removal of submandibular stones. Arch Otolaryngol Head Neck Surg 2001;127:432-6.

6 Cho W, Lim D, Park H. Transoral sonographic diagnosis of submandibular duct calculi. J Clin Ultrasound 2014;42:125-128.

7 Abdel-Wahed N, Amer ME, Abo-Taleb NS. Assessment of the role of cone beam computed sialography in diagnosing salivary gland lesions. Imaging Sci Dent 2013;43:17-23.

8 Milton CM, Thomas BM, Bickerton RC. Morbidity study of submandibular gland excision. Ann R Coll Surg Engl 1986;68:148-50.

9 Hald J, Andreassen UK. Submandibular gland excision: short- and long-term complications. ORL J Otorhinolaryngol Relat Spec 1994;56:87-91.

10 Marchal F. A combined endoscopic and external approach for extraction of large stones with preservation of parotid and submandibular glands. Laryngoscope 2007;117:373-7.

11 Walvekar RR, Bomeli SR, Carrau RL, et al. Combined approach technique for the management of large salivary stones. Laryngoscope 2009;119:1125-9.

12 Capaccio P, Clemente IA, McGurk M, et al. Transoral removal of hiloparenchymal submandibular calculi: a long-term clinical experience. Eur Arch Otorhinolaryngol 2011;268:1081-6.

13 Xiao JQ, Sun HJ, Qiao QH, et al. Evaluation of sialendoscopy-assisted treatment of submandibular gland stones. J Oral Maxillofac Surg 2017;75:309-316.

14 Guerre A, Katz P. Extracorporeal shockwave lithotripsy (ESWL) for salivary gland stones: a retrospective study of 1571 patients. Rev Stomatol Chir Maxillofac 2011;112:75-9.

15 Gillespie MB, O'Connell BP, Rawl JW, et al. Clinical and quality-of-life outcomes following gland-preserving surgery for chronic sialadenitis. Laryngoscope 2015;125:1340-4.

16 Luers JC, Grosheva M, Stenner M, et al. Sialoendoscopy: prognostic factors for endoscopic removal of salivary stones. Arch Otolaryngol Head Neck Surg 2011;137:325-9.

17 Ottaviani F, Capaccio P, Campi M, et al. Extracorporeal electromagnetic shock-wave lithotripsy for salivary gland stones. Laryngoscope 1996;106:761-4.

18 Iro H, Zenk J, Waldfahrer F, et al. Extracorporeal shock wave lithotripsy of parotid stones: results of a prospective clinical trial. Ann Otol Rhinol Laryngol 1998;107:860-4.

19 Koch M, Mantsopoulos K, Schapher M, et al. Intraductal pneumatic lithotripsy for salivary stones with the StoneBreaker: preliminary experience. Laryngoscope 2016;126:1545-50.

20 Kroll T, May A, Wittekindt C, et al. Cone beam computed tomography $(C B C T)$ sialography - an adjunct to salivary gland ultrasonography in the evaluation of recurrent salivary gland swelling. Oral Surg Oral Med Oral Pathol Oral Radiol 2015;120:771-5.

Received: September 15, 2016 - Accepted: December 12, 2016

Address for correspondence: Pasquale Capaccio, Department of Biomedical, Surgical and Dental Sciences, Fondazione I.R.C.C.S. Policlinico, Mangiagalli e Regina Elena, University of Milan, via F. Sforza 35, 20122 Milano, Italy. Tel. +39 02 50320245. Fax +39 02 50320248. E-mail: pasquale.capaccio@unimi.it 